\title{
Effects of co-occurrence of invading Procambarus clarkii and Pomacea canaliculata on Vallisneria denseserrulata-dominated clear-water ecosystems: a mesocosm approach
}

\author{
Jian Gao ${ }^{1, *}$, Cheng Yang ${ }^{1}$, Zehui Zhang ${ }^{1}$, Zhengwen Liu ${ }^{2}$ and Erik Jeppesen ${ }^{3,4,5,6}$ \\ ${ }^{1}$ Hubei Province Key Laboratory of Ecological restoration of Lakes and Rivers and Algal Utilization, School of Civil and Environmental \\ Engineering, Hubei University of Technology, Wuhan 430068, PR China \\ 2 State Key Laboratory of Lake Science and Environment, Nanjing Institute of Geography and Limnology, Chinese Academy \\ of Sciences, Nanjing 210008, PR China \\ ${ }^{3}$ Department of Bioscience, Aarhus University, 8600 Silkeborg, Denmark \\ ${ }^{4}$ Sino-Danish Centre for Education and Research (SDC), Beijing, PR China \\ ${ }^{5}$ Limnology Laboratory, Department of Biological Sciences and Centre for Ecosystem Research and Implementation, Middle East \\ Technical University, Ankara, Turkey \\ ${ }^{6}$ Institute of Marine Sciences, Middle East Technical University, Mersin, Turkey
}

Received: 14 April 2021 / Accepted: 22 July 2021

\begin{abstract}
Single invaders often substantially alter ecosystems, but the potential impacts by multiple invaders remain understudied. The golden apple snail (Pomacea canaliculata) and the red swamp crayfish (Procambarus clarkii) are two widespread coinvaders. To test the effects of co-occurrence of the two species on a clear-water macrophyte state, we performed a 20-day experiment in 16 mesocosms (4 contained only two snails, 4 contained only two crayfishes, 4 contained two snails and two crayfishes, and 4 controls). Comparing with the control, the leaf length, number, and biomass of Vallisneria denseserrulata had decreased in the snail-only and crayfish-only treatments. In the crayfish-only treatment, total nitrogen, total phosphorus and total suspended solids had increased compared with the control, while they did not differ between the snail-only and the control treatment. Nutrients and turbidity concentrations did not differ between the snail + crayfish and the crayfish-only treatment, and plant biomass did not differ between the snail + crayfish and the snail-only treatment. These findings suggest that golden apple snails mainly affected the lake ecosystem by plant grazing, while red swamp crayfishes disturbed the sediment by increasing nutrients in the water and through resuspension. These snail and crayfish together had mainly additive effects on macrophyte and the physico-chemical variables studied.
\end{abstract}

Keywords: Biological invasions / red swamp crayfish / golden apple snail / submerged macrophytes

Résumé - Effets de la co-occurrence des envahisseurs Procambarus clarkii et Pomacea canaliculata sur les écosystèmes d'eau claire dominés par Vallisneria denseserrulata: une approche en mésocosme. Les envahisseurs seuls modifient souvent de manière substantielle les écosystèmes, mais les impacts potentiels de plusieurs envahisseurs restent peu étudiés. L'escargot-pomme (Pomacea canaliculata) et l'écrevisse de Louisiane (Procambarus clarkii) sont deux co-envahisseurs très répandus. Pour tester les effets de la co-occurrence de ces deux espèces sur l'état des macrophytes en eau claire, nous avons réalisé une expérience de 20 jours dans 16 mésocosmes ( 4 contenant seulement deux escargots, 4 contenant seulement deux écrevisses, 4 contenant deux escargots et deux écrevisses, et 4 témoins). Par rapport au témoin, la longueur, le nombre et la biomasse des feuilles de Vallisneria denseserrulata ont diminué dans les tests avec escargots seulement et avec écrevisses seulement. Dans le test avec écrevisses uniquement, l'azote total, le phosphore total et les solides en suspension totaux ont augmenté par rapport au témoin, alors qu'ils ne différaient pas entre le test avec escargots uniquement et le test témoin. Les concentrations de nutriments et la turbidité ne différaient pas entre le test escargot+écrevisse et le test écrevisse seule, et les paramètres végétaux ne différaient pas entre le test escargot+écrevisse et le test

\footnotetext{
*Corresponding author: jgao13@hotmail.com
} 
escargot seul. Ces résultats suggèrent que les escargot-pomme ont principalement affecté l'écosystème du lac en broutant les plantes, tandis que les écrevisses de Louisiane ont perturbé les sédiments en augmentant les nutriments dans l'eau et la remise en suspension. L'ensemble de ces escargots et écrevisses ont principalement eu des effets additifs sur les macrophytes et les variables physico-chimiques étudiées.

Mots clés : Invasions biologiques / écrevisse de Louisiane / escargot-pomme / macrophytes immergés

\section{Introduction}

Managers widely apply restoration of submerged macrophytes to counteract eutrophication after external nutrient input reductions in shallow lakes (Jeppesen et al., 1998; Liu et al., 2018b). Submerged macrophytes are crucial in stabilizing clear-water conditions in shallow lakes (Ferreira et al., 2018; Hilt et al., 2018) as they increase nutrient retention, stabilize the water column, reduce sediment resuspension (Horppila and Nurminen, 2003; Nurminen and Horppila, 2009), and suppress phytoplankton growth through competition by allelopathy (Van Donk and van de Bund, 2002). Moreover, they can provide a refuge for zooplankton against fish predation, resulting in a higher zooplankton biomass and enhanced grazing on phytoplankton (Jeppesen et al., 2005).

Efforts to improve the water quality by restoring aquatic ecosystems to a submerged macrophyte-dominated state require a detailed understanding of how macrophyte communities respond to various stressors in space and time, including herbivory (Wood et al., 2017; Paz et al., 2019). Invasion of non-native benthic animals, such as golden apple snail (Pomacea canaliculata) and the red swamp crayfish (Procambarus clarkii), may enhance herbivory and diminish the abundance of submerged macrophytes (Carlsson et al., 2004; van der Wal et al., 2013) in shallow lakes, directly by grazing or indirectly by increasing resuspension of sediment and the internal nutrient loading (Angeler et al., 2001; Carlsson et al., 2004).

Red swamp crayfish and golden apple snail currently appear to be two of the most widespread invasive species in Chinese subtropical and tropical freshwater ecosystems (Zhan et al., 2016). Red swamp crayfish is native to the south-central United States and north-eastern Mexico but was introduced in China in the 1920s (Dai, 1983), and golden apple snail is native to South America and was introduced in China in the 1980s (Yang et al., 2010). As ecosystem engineers, omnivorous red swamp crayfish may reduce the standing stock of macrophytes through direct consumption (Rodríguez et al., 2003; Alcorlo et al., 2004) or by increasing water turbidity through sediment resuspension (Haubrock et al., 2019). They may also diminish the macrophyte biomass through non-consumptive plant shredding (Nyström et al., 2001). Accordingly, they may lead to a severe reduction of macrophyte abundance in the lakes to which they are introduced (Oficialdegui et al., 2020). This nonnative crayfish also preys on aquatic animals, including snails (Yamanishi et al., 2012). Also, the voracious herbivore golden apple snail (Tamburi and Martín, 2009a) constitutes a major threat to aquatic macrophytes (Gilioli et al., 2017; Paz et al., 2019). The effects of these two invading species on aquatic vegetation, water quality, and ecosystem services have been studied individually (Carlsson et al., 2004; Oficialdegui et al., 2020), whereas the overall effects of their co-occurrence remain poorly understood.

Golden apple snails and red swamp crayfishes coexist in a variety of waterbodies such as wetlands, lakes, and canals in central and south China and Japan (Yamanishi et al., 2012; Zeng et al., 2013), possibly because the large size of the golden apple snail make it less vulnerable to crayfish predation (Li, 2011). Golden apple snails and red swamp crayfishes use similar benthic habitats and plant resources (i.e., interference competition or predation; Yusa et al., 2006), and their combined effects may be relatively complex. A meta-analysis revealed that the effects of simultaneous invasion by two invaders (co-invasion) using the same or similar habitats and resources differ from their individual effects (Jackson, 2015).

We experimentally investigated the individual and combined effects of golden apple snails and red swamp crayfishes on the submerged macrophyte $V$. denseserrulata (Makino) widespread in Asia and the associated physical and chemical properties. We hypothesized that co-occurrence of the two invasive species enhances their effects on $V$. denseserrulata and the associated clear-water state. Examining the joint effects of an invasive omnivore and an invasive herbivore on submerged macrophytes in freshwater environments may further our understanding of the effects of multi-invaders.

\section{Materials and methods}

\subsection{Experimental mesocosm setup}

The mesocosm experiment was performed in 16 circular plastic tanks containing sediment and water (upper diameter $=85 \mathrm{~cm}$, bottom diameter $=65 \mathrm{~cm}$, height $=85 \mathrm{~cm}$, sediment depth $=15 \mathrm{~cm}$, water depth $=50 \mathrm{~cm}$ ). The tanks were placed in a transparent organic glass-covered outdoor experimental house without walls. Sediment (total nitrogen $[\mathrm{TN}]=1.54 \mathrm{mg} \mathrm{g}^{-1}$; total phosphorus $[\mathrm{TP}]=0.39 \mathrm{mg} \mathrm{g}^{-1}$ ) was obtained from Xunsi River, an outlet channel of a shallow lake in Wuhan City. The sediment was air-dried, powdered, and mixed to homogeneity after removing coarse debris and clumps. An approximately 15-cm-thick layer of homogenized sediment was added to each mesocosm, which was then filled with tap water $\left(\mathrm{TN}=1.08 \mathrm{mg} \mathrm{L}^{-1}, \mathrm{TP}=0.11 \mathrm{mg} \mathrm{L}^{-1}\right)$. The mesocosms were exposed to natural sunlight and equilibrated for 2 months, and $30 \mathrm{~V}$. denseserrulata were then planted in each mesocosm. The experiment started after 6 months, when $V$. denseserrulata covered most of the tank bottom. The experiment period was from September 30 to October 20, 2019, and the mesocosms were exposed to natural sunlight for its entire duration. The water temperatures recorded from the first to the last 
sampling were (mean value $\pm \mathrm{SD}$ ): $23.9 \pm 0.1{ }^{\circ} \mathrm{C}, 24.5 \pm 0.1{ }^{\circ} \mathrm{C}$, $20.6 \pm 0.1^{\circ} \mathrm{C}, \quad 20.6 \pm 0.1^{\circ} \mathrm{C}, \quad 22.0 \pm 0.2^{\circ} \mathrm{C}, \quad 17.8 \pm 0.1^{\circ} \mathrm{C}$, respectively.

Adult golden apple snails were used in the experiments because red swamp crayfish reportedly prey on juvenile snails (Yusa et al., 2006). Only two adult golden apple snails (mean weight: $73.4 \pm 1.9 \mathrm{~g}$; mean total length: $5.9 \pm 0.2 \mathrm{~cm}$ ) were added to each of four mesocosms (snail-only treatment: $\mathrm{S}-\mathrm{O}$ treatment), and only two adult male red swamp crayfishes (mean weight: $41.9 \pm 0.9 \mathrm{~g}$; mean total length: $9.9 \pm 0.4 \mathrm{~cm}$ ) were randomly added to each of another four mesocosms (crayfish-only treatment: $\mathrm{CF}-\mathrm{O}$ treatment). To investigate the additive effects of the two species, two golden apple snails and two red swamp crayfishes were both added to each of an additional four mesocosms (snail + crayfish treatment: $\mathrm{S}+\mathrm{CF}$ treatment). By using two individuals of each species in the combined treatment, we simulated a short-term effect of a co-invasion of the two species, acknowledging that the higher total biomass of the two species in the combined treatments would not be realistic for comparison with the single lower total biomass treatment in the long term if the two species have additive effects on the macrophytes. The remaining four mesocosms held no snails or crayfishes and served as control (control treatment: $\mathrm{CK}$ treatment). The snails and crayfishes were maintained in $80-\mathrm{L}$ tanks with $V$. denseserrulata for 2 weeks before their introduction to the mesocosms.

\subsection{Sampling and analysis}

At approximately 10 am every 4 days, water samples were collected from the tanks $10 \mathrm{~cm}$ below the surface for nutrient analyses and chlorophyll $a(\mathrm{Chl} a)$ determination. The samples were analyzed using Chinese standard methods (China EPA, 2009), which correspond to US standards (APHA, 1998). TN and TP concentrations were determined spectrophotometrically after thawing with combined persulfate digestion. The Chl $a$ concentration was determined spectrophotometrically after sample filtration through cellulose acetate filters and extraction of the filtered material with $90 \%$ acetone. Water was passed through $\mathrm{GF} / \mathrm{C}$ filters to measure total suspended solids (TSS) concentrations after drying at $105^{\circ} \mathrm{C}$ for $24 \mathrm{~h}$.

The number of broken leaves floating on the water in each mesocosm was recorded every 2 days. At the end of the experiment, all visible $V$. denseserrulata were harvested by hand from each tank after emptying the tank. The biomass (wet weight), mean leaf length and number of $V$. denseserrulata were recorded.

\subsection{Statistical analyses}

The effects of the various treatments on mean number of broken leaves, TSS, Chl $a$ (phytoplankton), TN, and TP were determined using repeated-measures analysis of variance (RM-ANOVA) with time as the repeated factor. If a significant difference was observed, Bonferroni test was used to detect which treatments differed. All data sets were examined for homogeneity of variances using Levene's tests. One-way ANOVA was performed to detect differences between pairwise comparisons on each sampling occasion. If a significant difference was observed, the Bonferroni test was used to detect

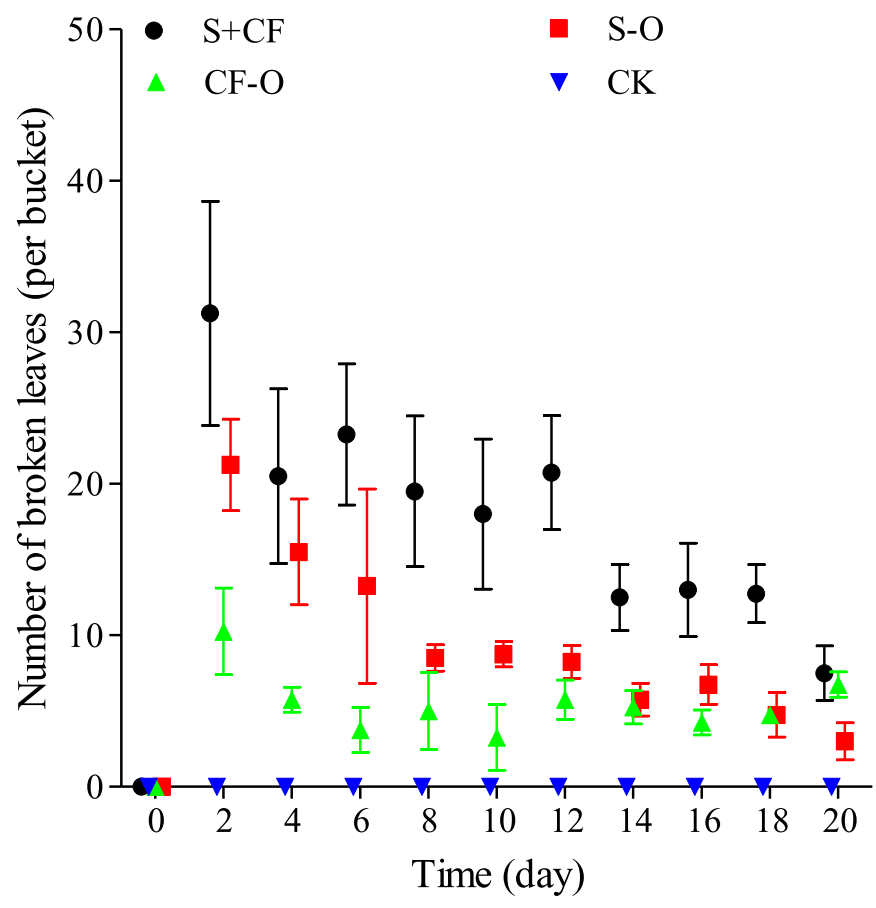

Fig. 1. Mean $( \pm \mathrm{SD}, n=4)$ number of broken leaves of Vallisneria denseserrulata along the study period in the different treatments. $\mathrm{S}+\mathrm{CF}$ denotes snail + crayfish, $\mathrm{S}-\mathrm{O}$ snail-only, $\mathrm{CF}-\mathrm{O}$ crayfish-only and $\mathrm{CK}$ is the control.

differing treatments. The effects of the various treatments on mean leaf length, biomass, and number of Vallisneria denseserrulata at the end of the study was performed to detect differences using one-way ANOVA with post hoc Bonferroni tests. For the one-way ANOVA, all data sets were examined for normality. Variance was not equally distributed in some cases, and Tamhane's T2 test was used to assess the differences between groups.

All statistical analyses were performed using SPSS 19.0 software (Statistical Product and Service Solutions, USA).

\section{Results}

\subsection{Effects of the snail and crayfish on V. denseserrulata}

The effects of the various treatments on number of broken leaves of $V$. denseserrulata differed (RM-ANOVAs, treatment effect, $P<0.01$ ) (Fig. 1). No broken leaves were observed in the $(\mathrm{CK})$ during the experimental period. More broken leaves occurred in the $\mathrm{S}+\mathrm{CF}$ than in the $\mathrm{S}-\mathrm{O}$ and $\mathrm{CF}-\mathrm{O}$ treatments (Bonferroni's Multiple Comparison Test, $P<0.01$; Fig. 1) and more broken leaves in the $\mathrm{S}-\mathrm{O}$ treatment than $\mathrm{CF}-\mathrm{O}$ in the treatment (Bonferroni's Multiple Comparison Test, $P<0.05$ ) (Fig. 1).

The effects of the various treatments on leaf length, biomass, and number of plants differed by the end of the study (one-way ANOVA, treatment effect, $P<0.01$; Fig. 2). The leaf length and biomass of plants did not differ between the $\mathrm{S}+\mathrm{CF}$ and the $\mathrm{S}-\mathrm{O}$ treatments. However, both were lower than in the 

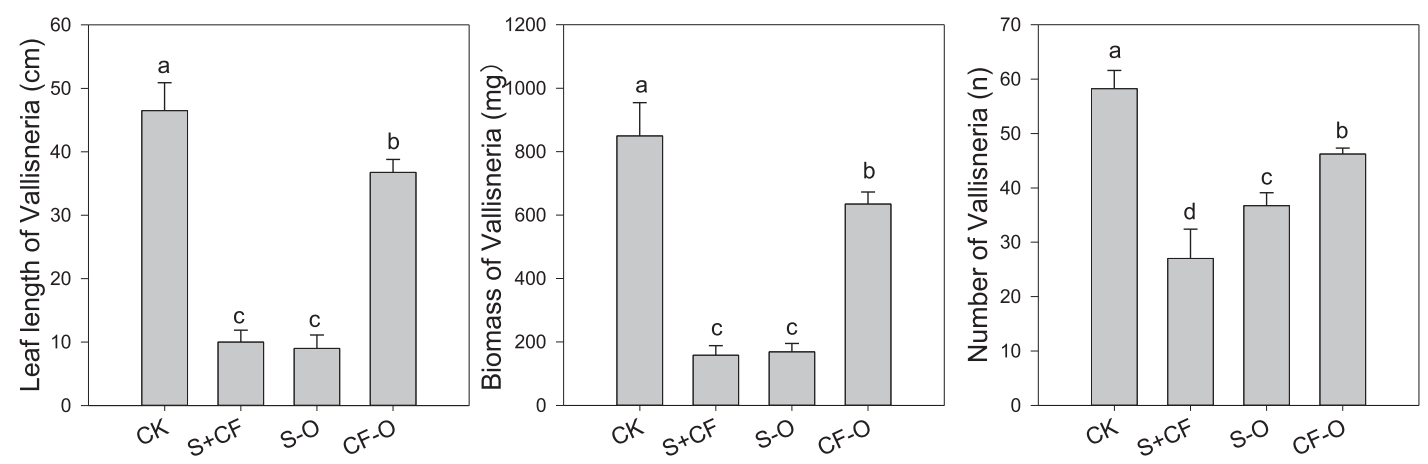

Fig. 2. Mean $( \pm \mathrm{SD}, n=4)$ leaf length, biomass (wet weight), and number of Vallisneria denseserrulata in the different treatments at the end of the study. $\mathrm{S}+\mathrm{CF}$ denotes snail + crayfish, $\mathrm{S}-\mathrm{O}$ snail-only, $\mathrm{CF}-\mathrm{O}$ crayfish-only and $\mathrm{CK}$ is the control.

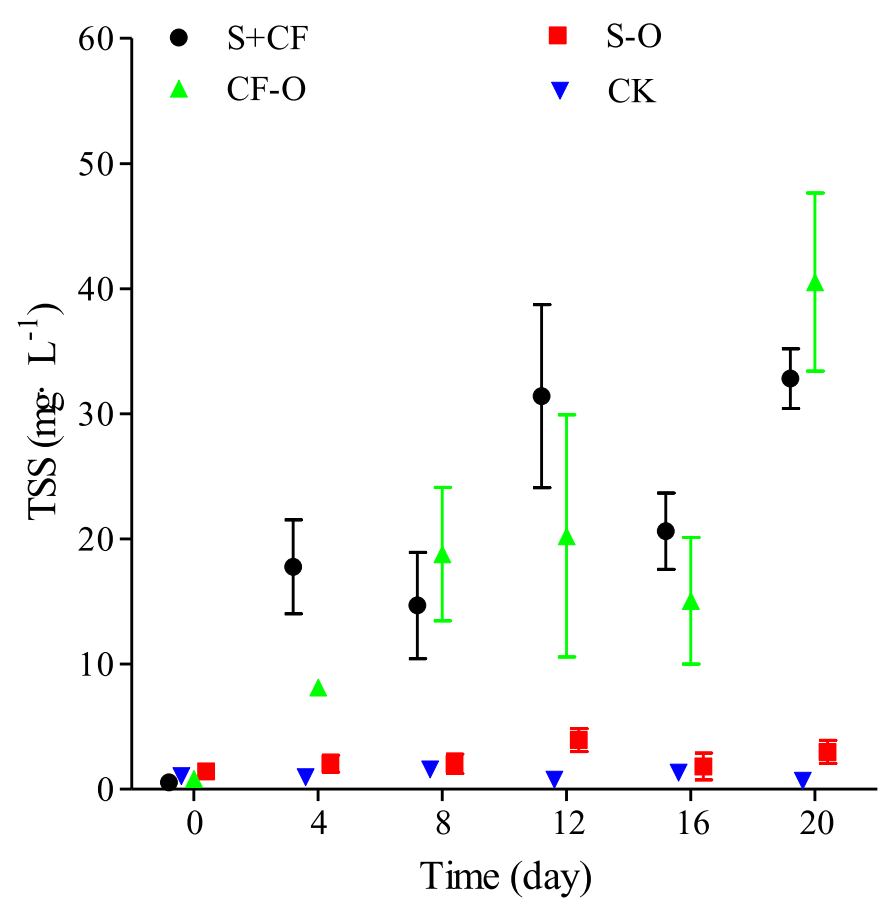

Fig. 3. Mean $( \pm \mathrm{SD}, n=4)$ total suspended solids (TSS) in the different treatments along the study period. $\mathrm{S}+\mathrm{CF}$ denotes snail + crayfish, $\mathrm{S}-\mathrm{O}$ snail-only, $\mathrm{CF}-\mathrm{O}$ crayfish-only and $\mathrm{CK}$ is the control.

$\mathrm{CF}-\mathrm{O}$ and $\mathrm{CK}$ treatments (Bonferroni's Multiple Comparison Test, $P<0.01$; Fig. 2). The number of plants was lowest in the $\mathrm{S}+\mathrm{CF}$ (Bonferroni's Multiple Comparison Test, $P<0.05$; Fig. 2) and lower in the $\mathrm{S}-\mathrm{O}$ than in the $\mathrm{S}+\mathrm{CF}$ treatments (Bonferroni's Multiple Comparison Test, $P<0.05$; Fig. 2).

\subsection{TSS concentrations and phytoplankton biomass}

The effects of the various treatments on TSS concentrations were different (RM-ANOVAs, treatment effect, $P<0.01$ ) (Fig. 3). Higher TSS concentrations occurred in the $\mathrm{S}+\mathrm{CF}$ and the $\mathrm{CF}-\mathrm{O}$ treatment than in the $\mathrm{CK}$ and the $\mathrm{S}-\mathrm{O}$ treatment (Bonferroni's Multiple Comparison Test, $P<0.01$; Fig. 3). TSS concentrations was similar in the CK and the $\mathrm{S}-\mathrm{O}$

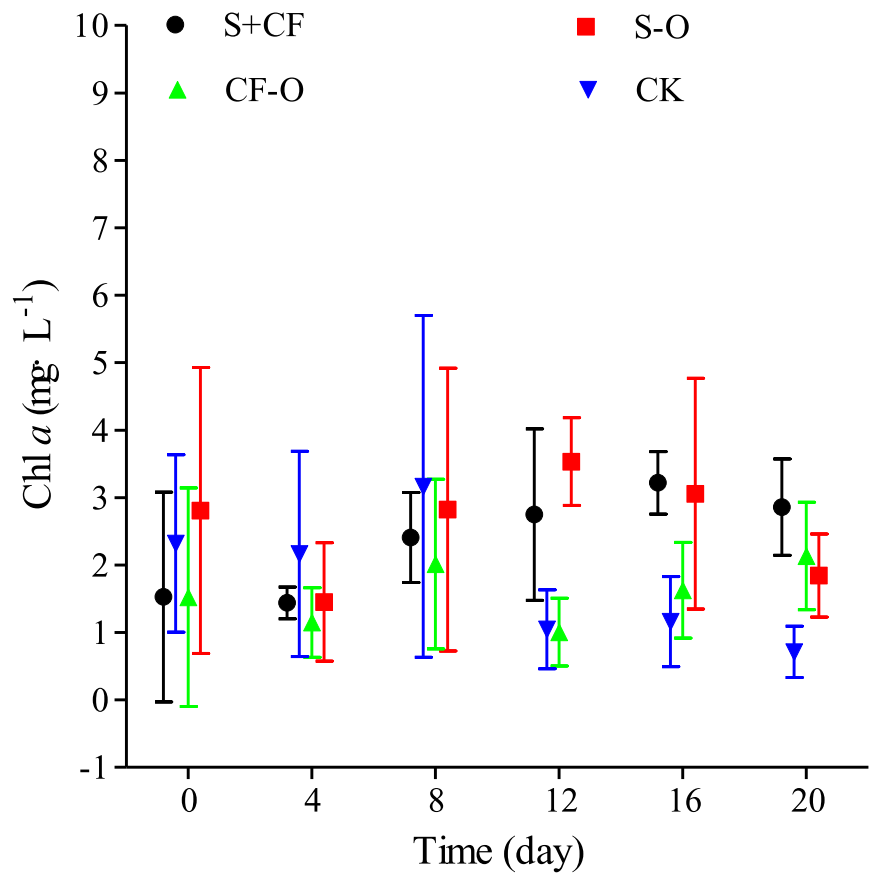

Fig. 4. Mean $( \pm \mathrm{SD}, n=4)$ chlorophyll a $(\mathrm{Chl} a)$ in the different treatments along the study period. $\mathrm{S}+\mathrm{CF}$ denotes snail + crayfish, $\mathrm{S}-\mathrm{O}$ snail-only, $\mathrm{CF}-\mathrm{O}$ crayfish-only and $\mathrm{CK}$ is the control.

treatments. Chl $a$ did not differ in any of the various treatments (RM-ANOVAs, treatment effect, $P>0.05$; Fig. 4).

\subsection{Physical and chemical factors}

The effects of the various treatments on TN and TP concentrations differed (RM-ANOVAs, treatment effect, $P<0.01$ ) (Fig. 3). Both higher TN and TP concentrations occurred in the $\mathrm{S}+\mathrm{CF}$ and the $\mathrm{CF}-\mathrm{O}$ treatment than in the $\mathrm{CK}$ and the $\mathrm{S}-\mathrm{O}$ treatment (Bonferroni's Multiple Comparison Test, $P<0.05$; Figs. 5 and 6$)$. TN and TP were similar in the $\mathrm{CK}$ and the $\mathrm{S}-\mathrm{O}$ treatments or in the $\mathrm{S}+\mathrm{CF}$ and the $\mathrm{CF}-\mathrm{O}$ treatments. However, higher TN occurred in the $\mathrm{S}-\mathrm{O}$ treatment than in the CK after 20 days (one-way ANOVA with Bonferroni's Multiple Comparison Test, $P<0.01$ ). 


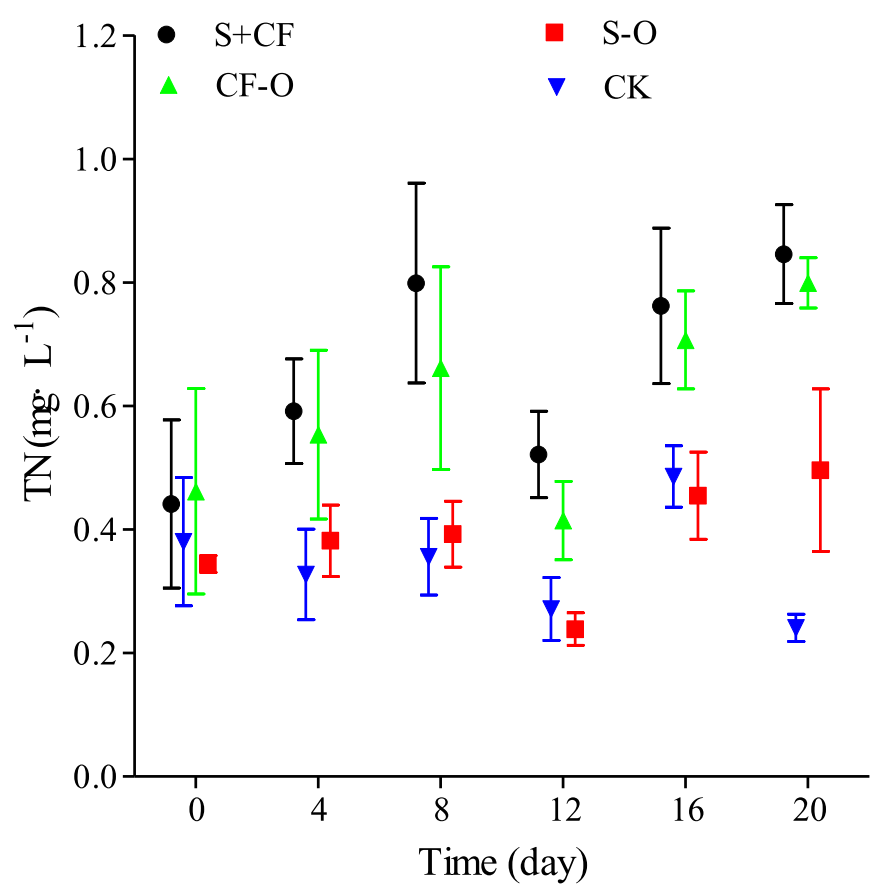

Fig. 5. Mean $( \pm \mathrm{SD}, n=4)$ total nitrogen $(\mathrm{TN})$ in the different treatments along the study period. $\mathrm{S}+\mathrm{CF}$ denotes snail + crayfish, $\mathrm{S}-\mathrm{O}$ snail-only, $\mathrm{CF}-\mathrm{O}$ crayfish-only and $\mathrm{CK}$ is the control.

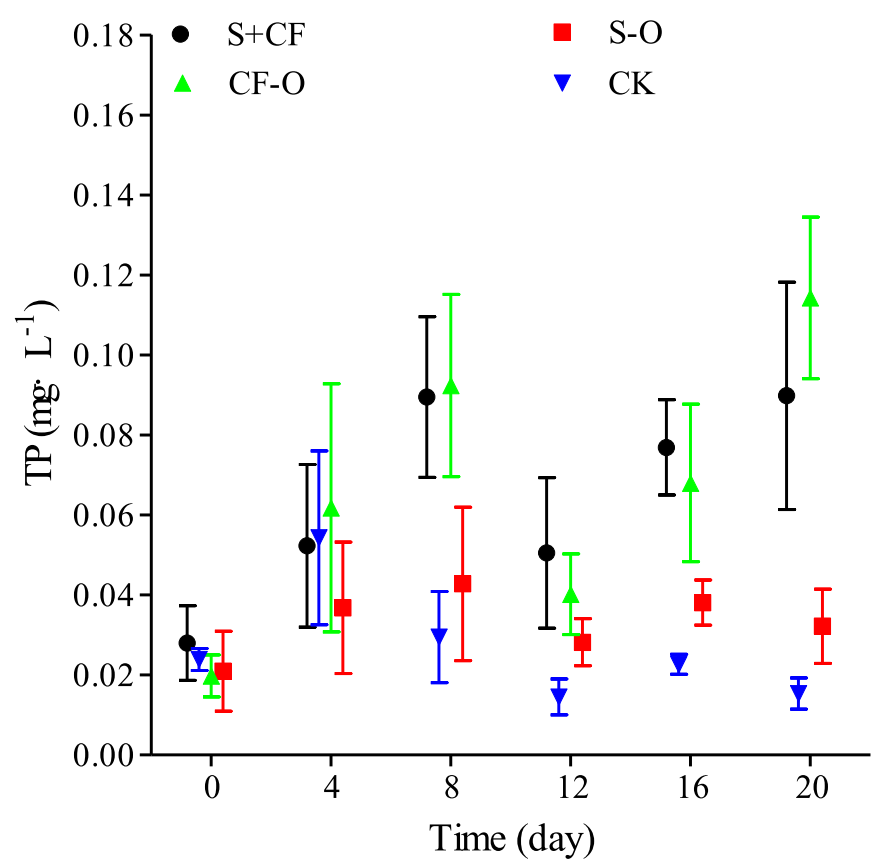

Fig. 6. Mean $( \pm \mathrm{SD}, n=4)$ total phosphorus $(\mathrm{TP})$ in the different treatments along the study period. $\mathrm{S}+\mathrm{CF}$ denotes snail + crayfish, $\mathrm{S}-\mathrm{O}$ snail-only, $\mathrm{CF}-\mathrm{O}$ crayfish-only and $\mathrm{CK}$ is the control.

\section{Discussion}

We found that both invaders, golden apple snail and red swamp crayfish, degraded the water quality by decreasing the biomass of submerged macrophytes and changing physical and chemical factors. The effects of the two species combined $(\mathrm{S}+\mathrm{CF})$ on water nutrients did not differ from those observed in the $\mathrm{CF}-\mathrm{O}$ treatment, and the combined impact on leaf length and biomass of plants did not differ from those of the S-O treatment.

Golden apple snails feed on vascular plants (macrophytophagous) and excrete nutrients to the water column, which may result in enhanced phytoplankton production (Fang et al., 2010; Manara et al., 2019). In our mesocosm experiment, the length, biomass, and number of $V$. denseserrulata were significantly lower in the tanks treated only with snails than in the CK tanks, and the plant biomass was reduced by $80 \%$ at the end of the experiment when snails were present. Specifically, females of golden apple snail usually reach larger sizes than males, and the females have a specific ingestion rate that is about $50 \%$ higher than that of males (Tamburi and Martín, 2009b). Furthermore, Carlsson and Brönmark (2006) demonstrated that small golden apple snail has higher foraging abilities than large ones, and small snails may cause a great damage to aquatic crops in wetlands, at least during the reproductive season (Tamburi and Martín, 2009b). Yang et al. (2021) recently suggested that the grazing preference of golden apple snail altered the competitive advantage of three submerged plants (namely $V$. denseserrulata, Hydrilla verticillata, and Myriophyllum spicatum), however, none of the submerged macrophytes could prevent golden apple snail from grazing on them. The concentrations of TN, TP, TSS, and $\mathrm{Chl} a$ in the $\mathrm{S}-\mathrm{O}$ treatment did not differ from the CK tanks during the 20-day experimental period. An experimental study performed for 34 days also found that the phytoplankton biomass and nutrient concentrations remained low after the introduction of golden apple snail (Fang et al., 2010). Manara et al. (2019), in contrast, reported that the presence of golden apple snails increased the concentration of Chl $a$ in the water in a longer lasting experiment (84 days). Our results showed that golden apple snails had a negative impact on submerged macrophytes abundance by grazing/breaking, but this did not increase the concentration of Chl $a$ and nutrients on the short term as submerged plants still maintained a relatively high biomass at the end of the experiment. However, on the long term, as seen in the study by Manara et al. (2019), the biomass of submerged plants may eventually drop to a level, which may reduce the refuge possibilities for zooplankton against predators and a lead major increase sediment resuspension and nutrient release, and potentially shift the lake to a turbid state (Jeppesen et al., 1998).

Severe reductions of macrophytes abundance have been observed after the introduction of red swamp crayfish (Rodríguez et al., 2003; van der Wal et al., 2013). Studies have suggested that red swamp crayfish can reduce the standing stock of macrophytes through direct consumption (Alcorlo et al., 2004), by diminishing the macrophyte biomass through non-consumptive plant shredding (van der Wal et al., 2013), and by increasing water turbidity through sediment resuspension (Angeler et al., 2001). In our mesocosm experiment, the concentrations of nutrients and TSS were significantly higher in the $\mathrm{CF}-\mathrm{O}$ treatment than in the $\mathrm{CK}$. The presence of crayfish had reduced the biomass of $V$. denseserrulata by $25 \%$ at the end of the experiment. However, this resuspension-mediated increase in nutrient supply produced by red swamp crayfish did not lead to an 
increase in phytoplankton biomass ( $\mathrm{Chl} a$ ) during the 20-day experimental period. Other studies have also shown that increasing turbidity by sediment resuspension inhibit growth and reduce the biomass of phytoplankton by decreasing the light penetration (Hellström, 1991; Wahl et al., 2011).

Previous studies have suggested that co-occurring invaders might have neutral, facilitative, or negative effects on native species or ecosystems (Jackson, 2015; Kuebbing and Nuñez, 2015) and that these effects can be additive (i.e. the sum of the effects of each invader; Preston et al., 2012; Kuebbing et al., 2016) or non-additive (Liu et al., 2018a) or antagonistic (Jackson, 2015). Multiple invaders are unlikely to act independently, the lowest plant biomass and the highest nutrient concentrations were expected to occur in the $\mathrm{S}+\mathrm{CF}$ treatment compared with the individual treatments and the $\mathrm{CK}$ since the combined ecological impacts of multiple invaders were frequently the sum of their independent effects (Jackson, 2015). The expectation was met in that higher turbidity and a lower standing stock of $V$. denseserrulata occurred in the treatments than in the CK. However, nutrient concentrations (TN, TP) and turbidity (TSS) did not differ between the $\mathrm{S}+\mathrm{CF}$ and the $\mathrm{CF}-\mathrm{O}$ treatment, and the length, biomass, and abundance of plants did not differ between the $\mathrm{S}+\mathrm{CF}$ and the snail treatment. The negative impact of snail and crayfish together on number of broken leaves was largest, their leave numbers being much higher in the combined treatment than in all other treatments (Fig. 1). Besides, the number of plants in this treatment tended to decrease (Fig. 2). It can be assumed that the crayfish mechanically have damaged the plants. In our study, the combined effects of the co-occurrence of the two invaders were mainly the sum of the effect of each invader where golden apple snail grazed on the plants, whereas the red swamp crayfish influenced the system by increasing the concentrations of nutrients and suspended solids in the water. It is unlikely that red swamp crayfish had direct consumptive effects on adult golden apple snails in our study due to the snail size used, but in a natural freshwater ecosystem red swamp crayfish would be able to prey on juvenile golden apple snails $(\mathrm{Li}, 2011)$. Therefore, in a natural freshwater ecosystem the combined effects of golden apple snails and red swamp crayfishes may be non-additive, but further research is needed to elucidate this in detail.

Our results are relevant for lake management and freshwater restoration. They underpin the importance of assessing the individual and combined effects of red swamp crayfishes and golden apple snails on submerged macrophytes and the associated physical and chemical properties. Both red swamp crayfishes and golden apple snails have been widely introduced in lakes and rivers throughout the world and have become invasive species in numerous regions, including China (Yusa et al., 2006; Duan, 2016), possibly requiring control measures. By preventing the invasion of red swamp crayfishes and golden apple snails from shallow lakes and rivers there is a higher likelihood of establishment of a clear-water state after nutrient loading reduction and thereby improve the water quality, and alleviate water quality problems otherwise associated with eutrophication, or to maintain and already existing clearwater state.

In conclusion, our study showed that golden apple snails mainly had a negative impact on submerged macrophytes by grazing and/or breaking its leaves, while red swamp crayfishes disturbed the sediment leading to higher resuspension and higher nutrient concentrations. Co-occurrence of the two species mainly had strong negative sum effects, making it more difficult to obtain or maintain a clearwater macrophytedominated state and high-water quality and clarity.

Acknowledgments. The authors thank Menghao Wang for field and laboratory support and Anne Mette Poulsen for language assistance. This study was supported by the Natural Science Foundation of Hubei Province (2020CFB537) and by the National Natural Science Foundation of China (Grant No. U2040220). EJ was supported by AQUACOSMplus (Network of Leading European AQUAtic MesoCOSM Facilities Connecting Mountains to Oceans from the Arctic to the Mediterranean), AnaEE Denmark (anaee.dk), and the TÜBITAK program BIDEB 2232 (project 118C250).

\section{References}

Alcorlo P, Otero M, Geiger W. 2004. Feeding preferences and food selection of the red swamp crayfish, Procambarus Clarkii, in habitats differing in food item diversity. Crustaceana 77: 435-453.

Angeler DG, Sánchez-Carrillo S, García G, Alvarez-Cobelas M. 2001. The influence of Procambarus clarkii (Cambaridae, Decapoda) on water quality and sediment characteristics in a Spanish floodplain wetland. Hydrobiologia 464: 89-98.

APHA. 1998. Standard methods for the examination of water and wastewater, 20th ed. Washington, DC: Amer Pub Health Assoc.

Carlsson NOL, Brönmark C, Hansson L-A. 2004. Invading herbivory: the golden apple snail alters ecosystem functioning in Asian wetlands. Ecology 85: 1575-1580.

Carlsson NOL, Brönmark C. 2006. Size-dependent effects of an invasive herbivorous snail (Pomacea canaliculata) on macrophytes and periphyton in Asian wetlands. Freshw Biol 51: 695-704.

China EPA. 2009. Water and wastewater monitoring and analysis methods, 4th ed. Chin Environ Sci Press.

Dai A. 1983. Introduction of a kind of aquatic resource - Crayfish (in Chinese). Chin J Zool 3: 51-53.

Duan QX. 2016. Studies on environmental impact factors and control techniques of two important invasive alien aquatic animals in Yunnan Province (in Chinese). Kunming: Yunan Normal University.

Fang L, Wong PK, Lin L, Qiu J. 2010. Impact of invasive apple snails in Hong Kong on wetland macrophytes, nutrients, phytoplankton and filamentous algae. Freshwat Biol 55: 1191-1204.

Ferreira TF, Crossetti LO, Motta Marques DML, Cardoso L, Fragoso Jr CR, van Nes EH. 2018. The structuring role of submerged macrophytes in a large subtropical shallow lake: clear effects on water chemistry and phytoplankton structure community along a vegetated-pelagic gradient. Limnologia 69: 142-154.

Gilioli G, Schrader G, Carlsson N, et al. 2017. Environmental risk assessment for invasive alien species: a case study of apple snails affecting ecosystem services in Europe. Environ Impact Assess Rev 65: $1-11$.

Haubrock PJ, Inghilesi AF, Mazza G, Bendoni M, Solari L, Tricarico E. 2019. Burrowing activity of Procambarus clarkii on levees: analysing behaviour and burrow structure. Wetl Ecol Manag 27: 497-511.

Hellström T. 1991. The effect of resuspension on algal production in a shallow lake. Hydrobiologia 213: 183-190. 
Hilt S, Nuñez AMM, Bakker ES, et al. 2018. Response of submerged macrophyte communities to external and internal restoration measures in north temperate shallow lakes. Front Plant Sci 19: $1-24$.

Horppila J, Nurminen L. 2003. Effects of submerged macrophytes on sediment resuspension and internal phosphorus loading in Lake Hiidenvesi (southern Finland). Water Res 37: 4468-4474.

Jackson MC. 2015. Interactions among multiple invasive animals. Ecology 96: 2035-2041.

Jeppesen E, Søndergaard M, Mazzeo N, et al. 2005. Lake restoration and biomanipulation in temperate lakes: relevance for subtropical and tropical lakes. In Restoration and Management of Tropical Eutrophic Lakes; Reddy, M.V., Ed.; Science Publishers Inc.: Enfield, NH, USA, pp. 331-359.

Jeppesen E, Søndergaard M, Søndergaard M, Christoffersen K. 1998. The structuring role of submerged macrophytes in lakes. New York, NY, USA: Springer.

Kuebbing SE, Nuñez MA. 2015. Negative, neutral, and positive interactions among nonnative plants: Patterns, processes, and management implications. Glob Change Biol 21: 926-934.

Kuebbing SE, Patterson CM, Classen TA, Simberloff D. 2016. Co-occurring nonnative woody shrubs have additive and nonadditive soil legacies. Ecol Appl 26: 1896-1906.

Li Y. 2011. Experience influencing the selection of predator, a case study with the red swamp crayfish Procambarus clarkii and the gold apple snail Pomacea canaliculated (in Chinese). Baoding: Hebei University.

Liu X, Wang S, Ke Z, et al. 2018a. More invaders do not result in heavier impacts: the effects of non-native bullfrogs on native anurans are mitigated by high densities of non-native crayfish J Anim Ecol 87: 850-862.

Liu Z, Hu J, Zhong P, et al. 2018b. Successful restoration of a tropical shallow eutrophic lake: strong bottom-up but weak top-down effects recorded. Water Res 146: 88-97.

Manara E, Maldonado MA, Martín PR. 2019. The role of an invader in its native range: could differential grazing by apple snails structure the submersed macrophytes assemblages in Southern Pampas (Argentina)? Hydrobiologia 828: 229-242.

Nurminen L, Horppila J. 2009. Life form dependent impacts of macrophyte vegetation on the ratio of resuspended nutrients. Water Res 43: 3217-3226.

Nyström P, Svensson O, Lardner B, Brönmark C, Granéli W. 2001. The influence of multiple introduced predators on a littoral pond community. Ecology 82: 1023-1039.

Oficialdegui FJ, Sánchez MI, Clavero M. 2020. One century away from home: how the red swamp crayfish took over the world. Rev Fish Biol Fisheries 30: 121-135.
Paz LE, Ferreira AC, Simonetti MA, Capitulo AR. 2019. Selection of macrophytes by a generalist invertebrate herbivore and potential impacts for stream rehabilitation. Aquat Bot 158.

Preston DL, Henderson JS, Johnson PTJ. 2012. Community ecology of invasions: direct and indirect effects of multiple invasive species on aquatic communities. Ecology 93: 1254-1261.

Rodríguez CF, Bécares E, Fernández-Alòez M. 2003. Shift from clear to turbid phase in Lake Chozas (NW Spain) due to the introduction of American red swamp crayfish (Procambarus clarkia). Hydrobiologia 506: 421-426.

Tamburi NE, Martín PR. 2009a. Reaction norms of size and age at maturity of Pomacea canaliculata (Gastropoda: Ampullariidae) under a gradient of food deprivation. J Moll Stud 75: 19-26.

Tamburi NE, Martín PR. 2009b. Feeding rates and food conversion efficiencies in the apple snail Pomacea canaliculata (Caenogastropoda: Ampullariidae). Malacologia 51: 221-232.

Van der Wal JEM, Dorenbosch M, Immers AK, et al. 2013. Invasive crayfish threaten the development of submerged macrophytes in lake restoration. PLOS ONE 8: e78579.

Van Donk E, van de Bund WJ. 2002. Impact of submerged macrophytes including charophytes on phyto- and zooplankton communities: allelopathy versus other mechanisms. Aquat Bot 72: 261-274.

Wahl DH, Wolfe MD, Santucci Jr VJ, Freedman JA. 2011. Invasive carp and prey community composition disrupt trophic cascades in eutrophic ponds. Hydrobiologia 678: 49-63.

Wood KA, O'Hare MT, Mcdonald C, et al. 2017. Herbivore regulation of plant abundance in aquatic ecosystems. Biol Rev 92: 1128-1141.

Yamanishi Y, Yoshida K, Fujimori N, Yusa Y. 2012. Predator-driven biotic resistance and propagule pressure regulate the invasive apple snail Pomacea canaliculata in Japan. Biol Invasions 14: 1343-1352.

Yang C, Kang Y, Gao J, et al. 2021. Effect of Pomacea canaliculata grazing on three submerged macrophytes and the related physicochemical factors (in Chinese). J Lake Sci 33: 1241-1253.

Yang Y, Hu Y, Li X, et al. 2010. Historical invasion, expansion process and harm investigation of Pomacea canaliculata in China (in Chinese). Chin Agric Sci Bull 26: 245-250.

Yusa Y, Sugiura N, Wada T. 2006. Predatory potential of freshwater animals on an invasive agricultural pest, the apple snail Pomacea canaliculate (Gastropoda: Ampullariidae), in southern Japan. Biol Invasions 8: 137-147.

Zeng Z, Wu H, Jiang Y, Peng G. 2013. Dynamics and impacts of invasion by exotic species to Poyang Lake national nature reserve (in Chinese). Ener Res Manag 4: 15-18.

Zhan A, Ni P, Xiong W, et al. 2016. Biological invasions in aquatic ecosystems in China. Chapter 4. In Wan F, et al. (eds.), Biological invasions and its management in China, Invading Nature Springer Series in Invasion Ecology 11. pp. 67-96.

Cite this article as: Gao J, Yang C, Zhang Z, Liu Z, Jeppesen E. 2021. Effects of co-occurrence of invading Procambarus clarkii and Pomacea canaliculata on Vallisneria denseserrulata-dominated clear-water ecosystems: a mesocosm approach. Knowl. Manag. Aquat. Ecosyst., 422, 29. 